\title{
Ditopic Receptors Capable of Hydrogen Bonding: Synthesis and Complexation Behaviour of Diaza Crown-Ethers having Melamine Sidearms
}

\author{
Silvio Quici,* Amedea Manfredi, Gianluca Pozzi, Marco Cavazzini, Angela Rozzoni \\ Centro CNR and Dipartimento di Chimica Organica e Industriale dell'Università degli Studi di Milano, \\ Via C. Golgi 19, I-20133 Milano, Italy.
}

Received 30 March 1999; revised 9 June 1999; accepted 25 June 1999

\begin{abstract}
The new ditopic receptors 1-3 (Figure 1) have been synthesized and their binding ability for alkaline and transition metal cations has ben investigated by halide and UV-Vis titrations. The recognition of complementary molecules through hydrogen bonding has been studied by ${ }^{1} \mathrm{H}-\mathrm{NMR}$. The simultaneous recognition of these two guests is an anti-cooperative event. 1999 Elsevier Science Ltd. All rights reserved.
\end{abstract}

Self-assembly of complementary molecules through the formation of multiple hydrogen bonds is a powerful tool for the creation of well-defined supramolecular architectures in the solid phase, in liquid crystals and in solution.' The formation of hydrogen bonds is favoured in non polar solvents, whereas it is negligible in aqueous media. The strength of any single noncovalent interaction is relatively weak anyhow, and manifold acceptor/donor hydrogen bonding units must interact to form supramolecular species in solution. The number and orientation of hydrogen bonding donor and acceptors sites present in the complementary molecules are then crucial for the assembly of supramolecular structures. A very interesting application of these general principles concerns the spontaneous formation of macrobicyclic cryptands from complementary diaza crownether units having adenine-terminated and thymine-terminated sidearms. ${ }^{2}$ These self-assembled "molecular boxes" were able to complex appropriately sized diammonium salts giving rise to defined three-component structures.

Aza crown-ethers are versatile receptors that we had previously used as building-blocks for luminescent molecular devices whose photophysical properties were reversibly modified upon complexation/decomplexation of ammonium salts or metal cations. ${ }^{3}$ In these devices, fluorescent units such as anthracene were covalently linked to the receptor core. Assembly of suitably functionalized aza crown-ethers and fluorescent molecules through hydrogen bonding could also be envisaged. Moreover, a similar approach could be useful for the contruction of artificial enzymes. ${ }^{4}$

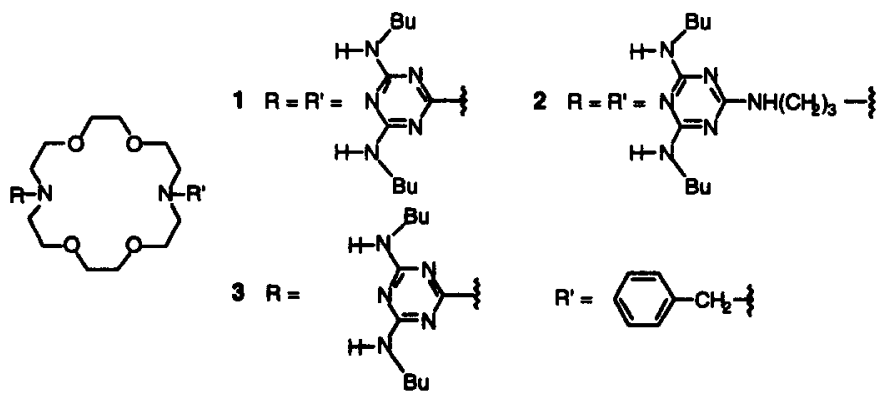

Figure 1 
Ditopic receptors capable of molecular recognition towards metal cations and assembly through the formation of multiple hydrogen bonds or other noncovalent interactions are currently investigated in our laboratory. In the present paper we report the synthesis of three of these receptors (Figure 1) where the metal cation binding subunit is a 1,7,10,16-tetraoxa-4,13-diazacyclooctadecane (N2-18-C-6), while an easily prepared alkylmelamine plays the role of hydrogen bonding subunit. A convenient access to related ditopic receptors having two different sidearms (e.g. receptor 3) is also described. The complexation behaviour of receptors 1 and 2 with respect to alkaline $\left(\mathrm{Li}^{+}, \mathrm{Na}^{+}, \mathrm{K}^{+}, \mathrm{Rb}^{+}\right)$and $\mathrm{NH}_{4}^{+}$cations has been investigated by halide determination in solid-liquid extraction experiments. UV-Vis titration was preferred for transition metal $\mathbf{C C o}^{2+}$, $\mathrm{Ni}^{2+}, \mathrm{Cu}^{2+}, \mathrm{Zn}^{2+}$ ) and $\mathrm{Mg}^{2+}$ cations. As shown by ${ }^{1} \mathrm{H}-\mathrm{NMR}$ studies, receptors 1 and 2 selectively bind complementary molecules such as glutarimide thanks to three hydrogen bond interactions. However, upon addition of metal cations these noncovalent interactions become extremely weak and the assembled hydrogen bonding structure is broken.

\section{Results and discussion}

Synthesis of receptors. The reported examples of lariat ethers bearing hydrogen bonding subunits involved the covalent assembly of N2-18-C-6 and nucleotides. ${ }^{2}$ The same aza crown-ether was chosen as the basic unit for our new ditopic receptors since it is commercially available and it is also a good complexation partner for several cations. ${ }^{5}$ Melamine derivatives were preferred to nucleotides as hydrogen bonding sidearms. Indeed, nucleophilic derivatization of 1,3,5-trichlorotriazine offers an efficient access to a number of compounds capable of space-oriented hydrogen bond interactions. ${ }^{6}$ Recent papers have nicely illustrated the enormous potential of melamines with respect to the creation of stable supramolecular architectures through hydrogen bonding. ${ }^{7}$ In order to obtain lipophilic ditopic receptors, 2-chloro-4,6-bis( $N$-butylamino)-1,3,5triazine 4 was tethered, either directly or through an $\mathrm{NH}\left(\mathrm{CH}_{2}\right)_{3}$ - spacer, to the nitrogen atoms of N2-18-C-6 (Scheme 1 and 2).

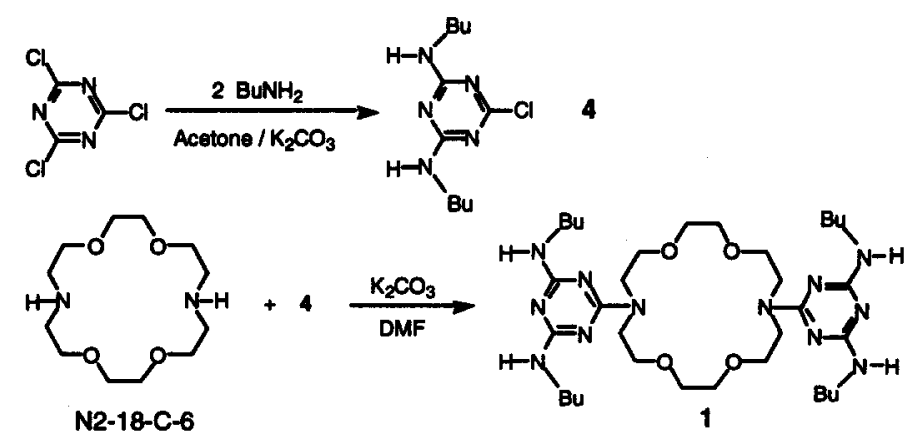

Scheme 1

The preparation of receptor 1 was easily achieved through direct condensation of N2-18-C-6 with 4 in DMF at $130^{\circ} \mathrm{C}$, in the presence of solid $\mathrm{K}_{2} \mathrm{CO}_{3}$ as base (Scheme 1).

The lariat ether 2 was synthesized following the route illustrated in Scheme 2. $N$-(3-bromopropyl)phthalimide 5 was prepared from 1,3-dibromopropane and potassium phthalimide under solid/liquid two phase conditions in the presence of 0.05 molar equivalents of $\mathrm{Bu}_{4} \mathrm{~N}^{+} \mathrm{Br}^{-}$as catalyst. Phthalimide 5 was then reacted with N2-18-C-6 in acetonitrile at $80{ }^{\circ} \mathrm{C}$ in the presence of solid $\mathrm{Na}_{2} \mathrm{CO}_{3}$ to give the corresponding bisphthalimido derivative 6 in $65 \%$ yield. Hydrolysis of 6 , conducted with hydrazine mono-hydrated, afforded bis-3-aminopropyl derivative 7 that was condensed with triazine 4 in the presence of $\mathrm{K}_{2} \mathrm{CO}_{3}$ to give receptor 2 in $46 \%$ yield. 


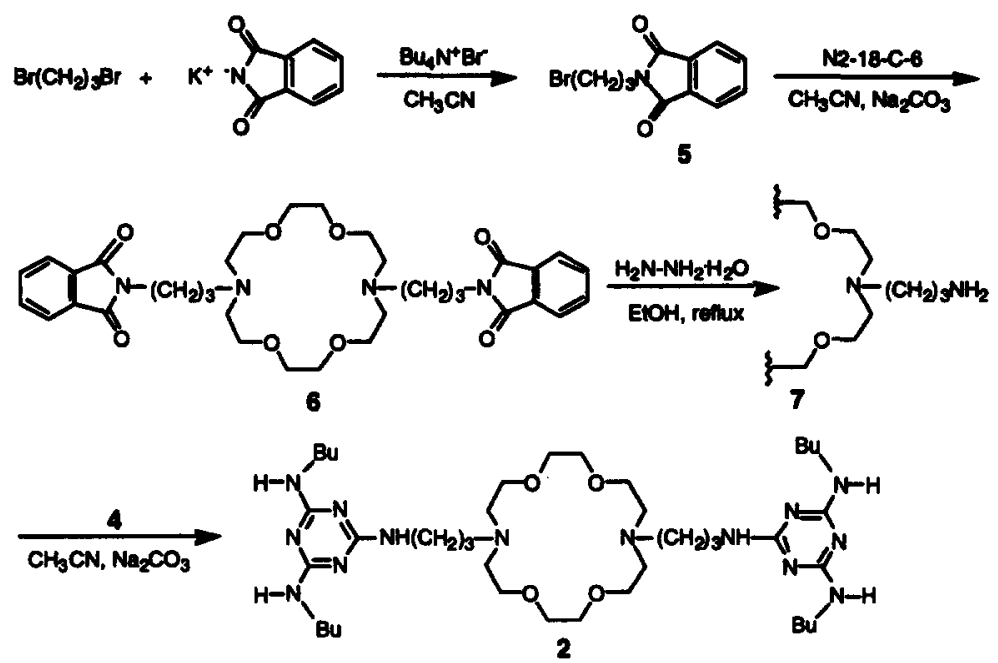

Scheme 2

Receptors 1 and 2 bearing two identical sidearms were ideal for studying the influence of the melamine units on the complexation behaviour of the aza crown-ether core, as well as the effects of bound metal cations on the association of the receptors with melamine complements (see later).

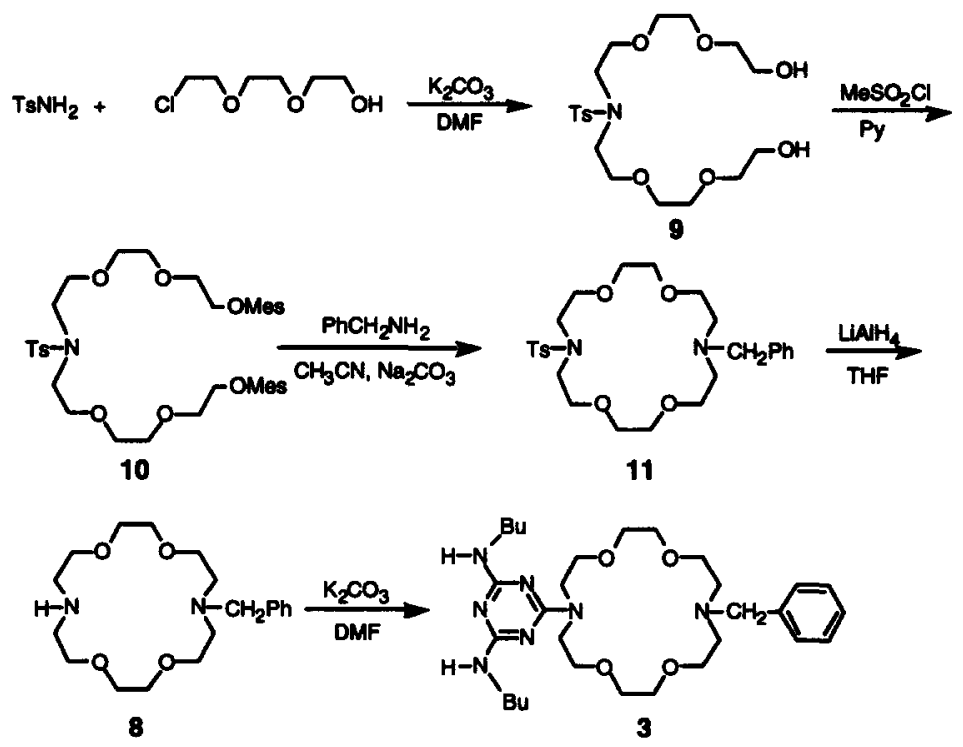

Scheme 3

However, the synthetic pathways developed for 1 and 2 were not suited for the selective preparation of lariat ethers having two different sidearms. Such compounds are very appealing in view of the creation of assembled arrays of receptor molecules through hydrogen bonding. ${ }^{26,8}$ As an alternative, we developed a sequence of reactions leading to the synthesis of the $N$-monosubstituted diaza crown-ether 8 (Scheme 3).Condensation of $p$-toluensulphonamide with 2-[2-(2-chloroethoxy)ethoxy] ethanol was carried out in DMF 
at $100{ }^{\circ} \mathrm{C}$ for $48 \mathrm{~h}$ to give diol 9 in $87 \%$ yield after column chromatography. This compound was quantitatively converted into the bis-methanesulphonate 10 , which was reacted with benzylamine in refluxing acetonitrile for $72 \mathrm{~h}$ in the presence of solid $\mathrm{Na}_{2} \mathrm{CO}_{3}$ as base. The $\mathrm{N}$-tosylamido- $\mathrm{N}$-benzylamino macrocycle 11 was thus obtained in $50 \%$ yield. Reductive detosylation of 11 with $\mathrm{LiAlH}_{4}$ in tetrahydrofuran at reflux for $\mathbf{4 8 ~ h}$ gave pure 8 as a thick oil in quantitative yield. This compound is a versatile starting material for the preparation of unsymmetrically substituted lariat ethers. For instance, it was functionalized with 4 in DMF at $130{ }^{\circ} \mathrm{C}$, in the presence of solid $\mathrm{K}_{2} \mathrm{CO}_{3}$ as base, affording the lariat ether 3 having one melamine and one benzyl sidearm. Straightforward elaboration of 3, such as debenzylation under reductive conditions ${ }^{9}$ followed by reaction with barbituric acid derivatives, can be conceived, leading to lariat ethers bearing complementary hydrogen bonding donor and acceptors sites.

Spectrophotometric UV-Vis titration of receptors 1 and 2. Complexation of receptors 1 and 2 with transition metal $\left(\mathrm{Co}^{2+}, \mathrm{Ni}^{2+}, \mathrm{Cu}^{2+}, \mathrm{Zn}^{2+}\right)$ and alkaline-earth $\left(\mathrm{Mg}^{2+}\right)$ cations was investigated by spectrophotometric UV-Vis titration of a known amount of 1 or 2 dissolved in $\mathrm{CH}_{3} \mathrm{CN}$, with aliquots of a $\mathrm{CH}_{3} \mathrm{CN}$ solution of $\mathrm{M}\left(\mathrm{ClO}_{4}\right)_{2}$. Concentrations were in the range $4.0-7.0 \times 10^{-5} \mathrm{M}$ for 1 and $1.8-3.0 \times 10^{-5} \mathrm{M}$

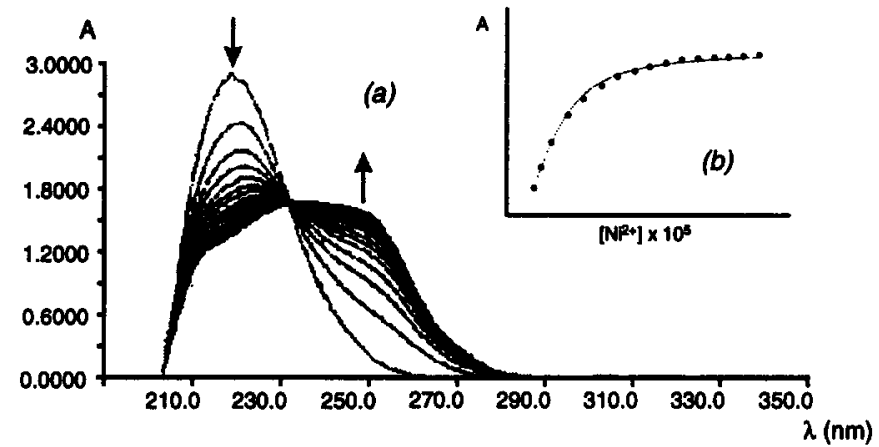

Figure 2. (a) Superimposed UV-Vis titration spectra in $\mathrm{CH}_{3} \mathrm{CN}$ of receptor 1 with $\mathrm{NiClO}_{4}$ and (b) titration diagram absorbance $(\mathrm{A}, \lambda=250 \mathrm{~nm})$ vs concentration of added metal cation $\left(C_{M}\right)$. for 2, while the inorganic salt concentrations were in the range 2.0 - $9.5 \times 10^{-3} \mathrm{M}$ (see Experimental Part). Upon addition of the organic solution of $\mathrm{M}\left(\mathrm{ClO}_{4}\right)_{2}$ a bathochromic shift of the absorption maxima of receptors 1 and 2 respectively, occurred. As expected the effect was more marked for receptor 1 in which the melamine chromophore is closer to the binding site, i.e. the aza crown moiety.

With both receceptors the presence of one or more isosbestic points in the superimposed UV-Vis spectra pointed to the presence of only two species in solution: the free receptor $L$ and a complex of defined stoichiometry $[M \subset L]^{2+}$ (Figure 2). ${ }^{10}$ Stability constants $K_{S}$ and stoichiometry of complexes $[M \subset L]^{2+}$ were determined by taking advantage of the progressive variation of absorbance in UV-Vis spectra at a fixed wavelength. ${ }^{11,12}$ In most titrations a well-defined hyperchromic effect was observed at $250 \mathrm{~nm}$, therefore the dependence of the absorbance on the metal cation concentration at this wavelength was studied.

$$
A=A_{0}+\frac{A_{l i m}-A_{0}}{2 C_{0}}\left[C_{0}+C_{M}+\frac{1}{K_{s}}-\sqrt{\left(C_{0}+C_{M}+\frac{1}{K_{s}}\right)^{2}-4 C_{0} C_{M}}\right]
$$

$\mathrm{A}=$ Actual absorbance value upon addition of a known amount of $\mathrm{M}\left(\mathrm{ClO}_{4}\right)_{2} ; \mathrm{A}_{0}=\mathrm{Absorbance}$ of the free receptor at $250 \mathrm{~nm} ; \mathrm{A}_{\text {lim }}$ $=$ Absorbance of the fully complexed receptor, $C_{0}=$ Initial concentration of the receptor; $C_{M}=$ Concentration of added metal cation.

The experimental data fit well to Equation 1 which is valid for $1: 1$ complexes. ${ }^{11}$ The $K_{S}$ values reported in Table 1 were thus calculated by nonlinear least-squares analysis of $A$ versus $C_{M}$. Both receptors 1 and 2 are able to bind transition metal ions: the stabilities of the resulting 1:1 complexes are similar and in the order of magnitude of those of the corresponding metal complexes of N2-18-C-6. ${ }^{13}$ 
The higher affinity of aza crown-ethers for transition metal cations when compared with macrocyclic polyethers is due to covalent contributions to the binding mode. ${ }^{5}$ The present results show that the presence of two melamine subunits in the receptor do not significantly alter these contributions, even in the case of receptor 1 , in which the two melamines are directly linked to the nitrogen atoms of the macrocycle.

Table 1. Stability Constants Calculated from UV-Vis Titrations. ${ }^{a}$

\begin{tabular}{cccc}
\hline $\mathrm{M}^{2+}$ & ionic radius $(\AA)^{\mathrm{b}}$ & $\log _{10} \mathrm{Ks}[\mathrm{M} \subset 1]^{2+}$ & $\log _{10} \mathrm{Ks}[\mathrm{M} \subset 2]^{2+}$ \\
\hline $\mathrm{Co}^{2+}$ & 0.75 & 5.28 & 5.26 \\
$\mathrm{Ni}^{2+}$ & 0.69 & 4.67 & 4.88 \\
$\mathrm{Cu}^{2+}$ & 0.77 & 5.03 & not determined \\
$\mathrm{Zn}^{2+}$ & 0.74 & 5.53 & 5.81 \\
$\mathrm{Mg}^{2+}$ & 0.72 & 5.15 & 4.96 \\
\hline
\end{tabular}

${ }^{a}$ See Experimental Section. ${ }^{b}$ Ref. [13].

Extent of complexation of receptors 1 and 2 with alkali and $\mathrm{NH}_{4}^{+}$cations. The complexation ability of receptors 1 and 2 toward alkali bromides ( $\mathrm{LiBr}, \mathrm{NaBr}, \mathrm{KBr}, \mathrm{RbBr}$ ) and ammonium chloride was studied under solid/liquid two-phase conditions by equilibrating known amounts of receptor dissolved in $\mathrm{CHCl}_{3}$ and an excess of solid inorganic salt (see Experimental Section). Values of the extent of complexation $(E(\%)$, defined as the ratio between the concentration of complexed receptor $\left[(M \subset L)^{+} X\right]$ and the initial receptor concentration $[\mathrm{L}]_{0}$ (Equation 2)) for receptors 1 and 2 are reported in Table 2.

$E(\%)=\left\{\left[(\mathrm{M} \subset \mathrm{L})^{+} \mathrm{X}^{-}\right] /[\mathrm{L}]_{0}\right\} \times 100$

Table 2. Extent of complexation of receptors 1 and 2 with alkali metals and ammonium halides. ${ }^{a}$

\begin{tabular}{cccc}
\hline Salt & ionic radius $(\AA)^{\mathrm{b}}$ & $E(\%) 1$ & $E(\%) 2$ \\
\hline $\mathrm{LiBr}$ & 0.76 & 55.0 & 10.4 \\
$\mathrm{NaBr}$ & 1.02 & 41.2 & 48.8 \\
$\mathrm{KBr}$ & 1.38 & 19.0 & 58.0 \\
$\mathrm{RbBr}$ & 1.52 & 11.0 & 18.6 \\
$\mathrm{NH}_{4} \mathrm{Cl}$ & - & 19.8 & 88.3 \\
\hline
\end{tabular}

'See Experimental Section. ${ }^{b}$ Ref. [13].

The behaviour of the two receptors was remarkably different. The affinity of receptor 2 for alkali cations matches that of N2-18-C-6 $\left(\mathrm{K}^{+}>\mathrm{Na}^{+}>\mathrm{Rb}^{+}>\mathrm{Li}^{+}\right)$, whereas the extent of complexation of 1 regularly decreases with the increase of the ionic radius of the cation. Two factors could jointly produce this effect: the high rigidity of receptor 1 , that induces preference for small cations, ${ }^{3 \mathrm{a}}$ and the proximity of the melamine subunits to the macrocyclic binding site that hinders the complexation of large cations. Another interesting difference was found with respect to the complexation of $\mathrm{NH}_{4}{ }^{+}$, that can be efficiently achieved only with receptor 2. The selectivity of macrocyclic polyethers for $\mathrm{NH}_{4}{ }^{+}$increases to the detriment of alkali cations when one or more oxygen atoms are replaced with nitrogen. ${ }^{14}$ Indeed, complexation involves hydrogen bonds between the donor atoms of the macrocycle and $\mathrm{NH}_{4}{ }^{+}$. The high extent of $\mathrm{NH}_{4}^{+}$complexation observed with 
receptor 2 is coherent with this view. On the other hand, nitrogen atom donors of receptor 1 are either too electron-poor or fixed in an unsuitable topological arrangement to be able to form hydrogen bonds with $\mathrm{NH}_{4}{ }^{+}$.

'H-NMR titration of receptors 1 and 2 with glutarimide and $\mathrm{ZnI}_{2}$ in $\mathrm{CDCl}_{3}$. The association ability of the ditopic receptors 1 and 2 with complementary molecules was studied in solution by 'H-NMR. Upon formation of hydrogen bonds networks, the chemical shift of the involved hydrogen atoms vary considerably. The existence of such interactions can thus be inferred from ${ }^{1} \mathrm{H}-\mathrm{NMR}$ titrations. ${ }^{2,8}$ Glutarimide 12 exhibits an acceptor/donor site pattern complementary to that of the melamine sidearms and was chosen as a complementary molecule for the two receptors. ${ }^{1} \mathrm{H}-\mathrm{NMR}$ titrations were carried out at $20^{\circ} \mathrm{C}$ by adding $10 \mu \mathrm{l}$ aliquots of a $4.5 \times 10^{-1} \mathrm{M}$ solution of 12 in $\mathrm{CDCl}_{3}$ to $0.6 \mathrm{ml}$ of a $1.5 \times 10^{-2} \mathrm{M}$ solution of receptor in the same solvent. Increase of the glutarimide concentration in solution led to the progressive broadening and downfield shift of the amido-H of 12 and of the amino-H's of the receptor. When 12 and the receptor were mixed in $2 / 1$ molar ratio, the amino-H's appeared as a single broad signal shifted downfield with respect to the free receptor $(+1.54 \mathrm{ppm}$ for 1 and $+1.47 \mathrm{ppm}$ for 2$)$, whereas the amido-H was too broad to be detected. Further addition of glutarimide (molar ratio $3 / 1$ ) resulted in the appearence of the amido-H peak of free glutarimide at $9.45 \mathrm{ppm}$. These observations were consistent with the formation of hydrogen-bonded species comprising two molecules of 12 and a single molecule of receptor. ${ }^{2}$

In order to verify whether the supramolecular aggregates were stable in the presence of metal cations, the following experiments were carried out. The $\mathrm{Zn}^{2+}$ complex of receptor 1 was prepared by magnetically stirring an excess of solid $\mathrm{ZnI}_{2}$ with a $\mathrm{CDCl}_{3}$ solution of the aza crown for $24 \mathrm{~h}$ under $\mathrm{N}_{2}$. Upon addition of 12 to the liquid phase, the broad ${ }^{1} \mathrm{H}-\mathrm{NMR}$ spectrum of the complex (amino-H's: $d=6.72 \mathrm{ppm}$ ) did not change, and the amido- $H$ peak of free glutarimide remained visible throughout the titration. On the other hand, the ${ }^{1} \mathrm{H}-\mathrm{NMR}$ spectrum recorded $2 \mathrm{~h}$ after addition of solid $\mathrm{ZnI}_{2}$ to the $\mathrm{CDCl}_{3}$ solution containing receptor 1 and 12 (molar ratio $2 / 1$ ) was identical to that of the $\mathrm{Zn}^{2+}$ complex of receptor 1 (Figure 3). Similar results were obtained for receptor 2.

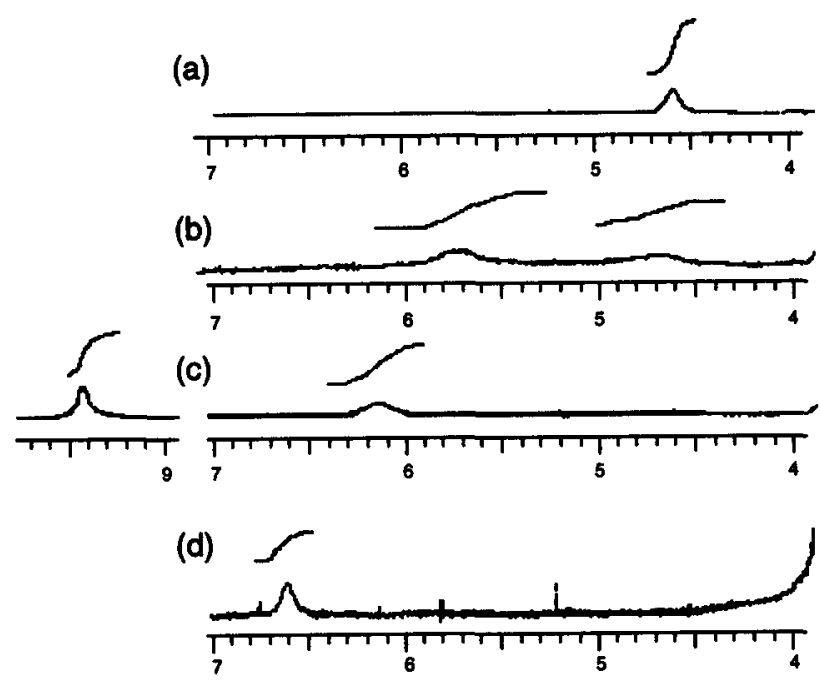

Figure 3. 'H-NMR spectra of (a) free receptor 1, (b) receptor 1 and glutarimide (molar ratio 1/1), (c) receptor 1 and glutarimide (molar ratio 1/3), and (d) $\mathrm{Zn}^{2+}$ complex of receptor 1 . 
Since neither UV-Vis absorption nor ${ }^{1} \mathrm{H}-\mathrm{NMR}$ spectrum of 2-chloro-4,6-bis( $N$-butylamino)-1,3,5-triazine 4 were affected by the presence of $\mathrm{ZnI}_{2}$, it was concluded that the complexation of the metal cation by the aza crown-ether moiety is responsible for the weakening of the hydrogen bond interactions between the receptors and glutarimide 12. The behaviour of the ditopic receptors is summarized in Scheme 4.

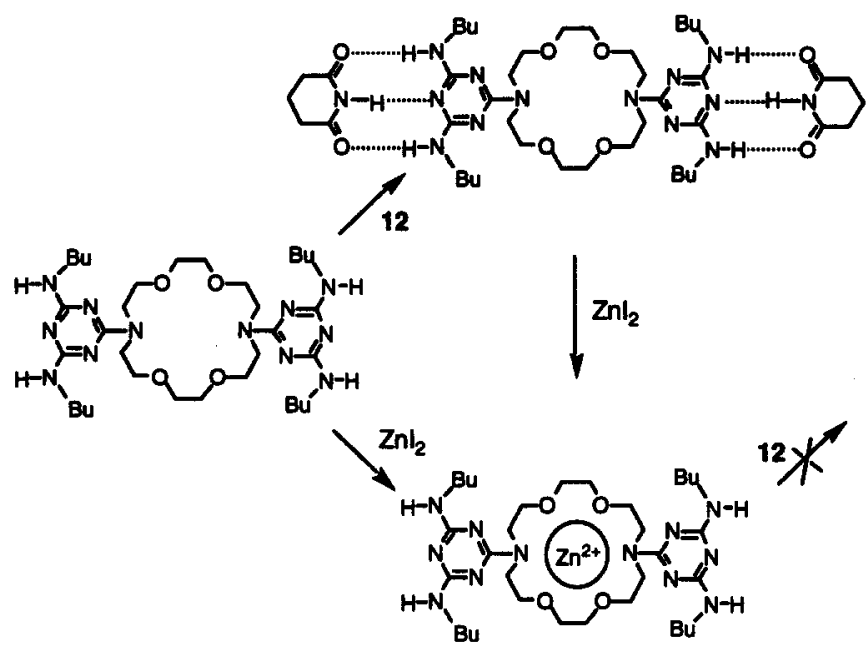

Scheme 4. Binding Behaviour of Receptor 1.

\section{Conclusions}

Aza crown-ethers having melamine-terminated sidearms are effective ditopic receptors capable of metal ions complexation and recognition of complementary neutral molecules through hydrogen bonds pairing. However, conformational and electronic density changes induced by metal cation complexation disrupt the hydrogen bond interactions and the ditopic receptors here described are not able to fulfil their twofold binding role simultaneously. This is in contrast with the behaviour shown by other ditopic receptors containing the aza crown unit, for which self-organization is achieved by means of noncovalent interactions other than hydrogen bonding. ${ }^{15}$

\section{Experimental section.}

UV-Vis spectra were recorded at $20{ }^{\circ} \mathrm{C}$ on a Lambda 6 Perkin-Elmer spectrophotometer in $\mathrm{CHCl}_{3}$ solutions. 'H-NMR spectra were recorded on a Varian XI 300 spectrometer with tetramethylsilane $(\delta=0)$ as internal standard. Melting points were measured on a Büchi 510 apparatus and are uncorrected. Potentiometric titrations were performed with a Titroprocessor E636 and a Metrohm Dosimat E635. Organic and inorganic reagents, ACS grade, were used without further purification.

2-Chloro-4,6-bis-(n-butylamino)-1,3,5-triazine (4). A solution of $n$-butylamine $(3.73 \mathrm{~g}, 51.0 \mathrm{mmol})$ in $30 \mathrm{ml}$ of acetone was added dropwise at RT to a stirred suspension of 2,4,6-trichloro-1,3,5-triazine (cyanuric cloride) $(4.87 \mathrm{~g}, 25.5 \mathrm{mmol})$ and solid $\mathrm{K}_{2} \mathrm{CO}_{3}(8.5 \mathrm{~g}, 61.5 \mathrm{mmol})$ in $70 \mathrm{ml}$ of acetone. The reaction mixture was heated at $60^{\circ} \mathrm{C}$ for $20 \mathrm{~h}$, then allowed to cool to RT and the solid filtered off. The residue was washed with weakly acidic water, filtered and dried in a vacuum dessicator for $24 \mathrm{~h}$. The dried precipitate was transferred into a Soxhlet apparatus and continously extracted at $40^{\circ} \mathrm{C}$ with $\mathrm{CH}_{2} \mathrm{Cl}_{2}$ for $20 \mathrm{~h}$. Evaporation of the solvent afforded $4.7 \mathrm{~g} \mathrm{(71 \% )}$ of 2-chloro-4,6-bis-(n-butylamino)-1,3,5-triazine 4 as a white solid; mp 216$218{ }^{\circ} \mathrm{C}$; [Found: $\mathrm{C}, 51.16 ; \mathrm{H}, 7.70 ; \mathrm{N}, 26.98 . \mathrm{C}_{11} \mathrm{H}_{20} \mathrm{ClN}_{5}$ requires $\left.\mathrm{C}, 51.25 ; \mathrm{H}, 7.84 ; \mathrm{N}, 27.16\right] ; \mathrm{v}_{\max }(\mathrm{KBr})$ 
$3256,3102,2922,2853,1645,1559,1410,1365,1105,798,745 \mathrm{~cm}^{-1} ;{ }^{1} \mathrm{H}-\mathrm{NMR}$ (DMSO- $\left.d_{6}\right) \delta 0.90(\mathrm{t}, 6 \mathrm{H}, \mathrm{J}=$ $7.0 \mathrm{~Hz}), 1.23-1.39(\mathrm{~m}, 4 \mathrm{H}), 1.40-1.55(\mathrm{~m}, 4 \mathrm{H}), 3.14-3.29(\mathrm{~m}, 4 \mathrm{H})$.

4,13-Bis-[2,4-bis-(n-butylamino)-1,3,5-triazin-6-yl]-1,7,10,16-tetraoxa-4,13-diazacyclooctadecane (1). Solid $\mathrm{K}_{2} \mathrm{CO}_{3}(3.0 \mathrm{~g}, 21.7 \mathrm{mmol})$ was added to a solution of 1,7,10,16-tetraoxa-4,13-diazacyclooctadecane N2$18-\mathrm{C}-6(0.48 \mathrm{~g}, 1.83 \mathrm{mmol})$ and the bis- $n$-butylamino derivative $4(0.95 \mathrm{~g}, 3.66 \mathrm{mmol})$ in $80 \mathrm{ml}$ of DMF; the resulting suspension was stirred at $130{ }^{\circ} \mathrm{C}$ for $18 \mathrm{~h}$. The reaction mixture was allowed to cool to $\mathrm{RT}$ and filtered through Celite; the precipitate was carefully washed with $30 \mathrm{ml}$ of DMF and the filtrates were evaporated to dryness under reduced pressure. The residue was taken up in $\mathrm{Et}_{2} \mathrm{O}$ to give, after filtration, $0.57 \mathrm{~g}$ (53\%) of an orange fine powdered solid $1 ; \mathrm{mp} 117-119^{\circ} \mathrm{C}$; [Found: $\mathrm{C}, 57.86 ; \mathrm{H}, 9.25 ; \mathrm{N}, 23.78 . \mathrm{C}_{34} \mathrm{H}_{64} \mathrm{~N}_{12} \mathrm{O}_{4}$ requires $\mathrm{C}, 57.93 ; \mathrm{H}, 9.15 ; \mathrm{N}, 23.84$ ]; $v_{\max }(\mathrm{KBr}) 3400,3271,2954,2930,2870,1560,1515,1430,1416$, $1365,1126,1070,810 \mathrm{~cm}^{-1} ;{ }^{1} \mathrm{H}-\mathrm{NMR}\left(\mathrm{CDCl}_{3}\right) \delta 0.91(\mathrm{t}, 12 \mathrm{H}, \mathrm{J}=7.2 \mathrm{~Hz}), 1.29-1.41(\mathrm{~m}, 8 \mathrm{H}), 1.46-1.55(\mathrm{~m}$, $8 \mathrm{H}), 3.28-3.34(\mathrm{q}, 8 \mathrm{H}, \mathrm{J}=6.3 \mathrm{~Hz}$ ), $3.61(\mathrm{~s}, 8 \mathrm{H}), 3.69$ (br. t, 8H, J = 5.5 Hz), 3.75-3.86 (m, 8H), 4.64 (br. s, $4 \mathrm{H}$, $\mathrm{D}_{2} \mathrm{O}$ exchange); MS-FAB( $\left(^{+}\right) \mathrm{m} / \mathrm{z} 704\left(\mathrm{M}^{+}\right)$, calcd. for $\mathrm{C}_{34} \mathrm{H}_{64} \mathrm{~N}_{12} \mathrm{O}_{4} \mathrm{~m} / \mathrm{z} 704$.

$N$-(3-Bromopropyl)-phthalimide (5). A mixture of 1,3-dibromopropane (27.2 $\mathrm{g}, 135 \mathrm{mmol})$, potassium phthalimide $(10 \mathrm{~g}, 54 \mathrm{mmol})$ and tetrabutylammonium bromide $(0.64 \mathrm{~g}, 2 \mathrm{mmol})$ in $140 \mathrm{ml}$ of acetonitrile was stirred at $80^{\circ} \mathrm{C}$ for $15 \mathrm{~h}$. After this time the reaction mixture was allowed to cool to RT and filtered through Celite; the precipitate was carefully washed with $100 \mathrm{ml}$ of $\mathrm{CH}_{3} \mathrm{CN}$ and the filtrates were evaporated to dryness under reduced pressure to afford $25.0 \mathrm{~g}$ of white solid. Purification by column cromatography ( $\mathrm{SiO}_{2}$, $\mathrm{CH}_{2} \mathrm{Cl}_{2}$ ) gave $10.5 \mathrm{~g}(72.4 \%)$ of 5 as a white solid: $\mathrm{mp} 74-76{ }^{\circ} \mathrm{C}$; [Found: $\mathrm{C}, 49.41 ; \mathrm{H}, 3.84 ; \mathrm{N}, 5.15$. $\mathrm{C}_{11} \mathrm{H}_{10} \mathrm{BrNO} \mathrm{N}_{2}$ requires $\left.\mathrm{C}, 49.27 ; \mathrm{H}, 3.77 ; \mathrm{N}, 5.22\right] ; v_{\max }(\mathrm{KBr}) 2927,1703,1443,1407,1230,1054,870,724$ $\mathrm{cm}^{-1}$; ${ }^{1} \mathrm{H}-\mathrm{NMR}\left(\mathrm{CDCl}_{3}\right) \delta 2.25$ (quint, $2 \mathrm{H}, \mathrm{J}=6.8 \mathrm{~Hz}$ ), $3.40(\mathrm{t}, 2 \mathrm{H}, \mathrm{J}=6.8 \mathrm{~Hz}$ ), $3.82(\mathrm{t}, 2 \mathrm{H}, \mathrm{J}=6.8 \mathrm{~Hz}), 7.67-$ $7.77(\mathrm{~m}, 2 \mathrm{H}), 7.80-7.86(\mathrm{~m}, 2 \mathrm{H})$.

4,13-Bis-(3-N-propylphthalimido)-1,7,10,16-tetraoxa-4,13-diazacyclooctadecane (6). Solid $\mathrm{Na}_{2} \mathrm{CO}_{3}$ $(8.9 \mathrm{~g}, 83.8 \mathrm{mmol})$ was added to a solution of N2-18-C-6 $(1.22 \mathrm{~g}, 4.66 \mathrm{mmol})$ and the phthalimido derivative 5 $(2.50 \mathrm{~g}, 9.32 \mathrm{mmol})$ in $100 \mathrm{ml}$ of $\mathrm{CH}_{3} \mathrm{CN}$ and the resulting suspension was stirred at $80{ }^{\circ} \mathrm{C}$ for $48 \mathrm{~h}$. The reaction mixture was then allowed to cool to RT and filtered through Celite. The Celite plug was carefully washed with $30 \mathrm{ml}$ of acetonitrile and the combined filtrates were evaporated. Purification of the residue by column cromatography $\left(\mathrm{SiO}_{2}, \mathrm{CH}_{2} \mathrm{Cl}_{2} / \mathrm{CH}_{2} \mathrm{OH}=8: 2 \mathrm{v} / \mathrm{v}\right)$ gave $2.02 \mathrm{~g}(65.5 \%)$ of 6 as yellow thick oil; [Found: $\mathrm{C}, 64.35 ; \mathrm{H}, 7.01 ; \mathrm{N}, 8.72 . \mathrm{C}_{34} \mathrm{H}_{44} \mathrm{~N}_{4} \mathrm{O}_{8}$ requires $\mathrm{C}, 64.13 ; \mathrm{H}, 6.98 ; \mathrm{N}, 8.79$ ]; $\mathrm{v}_{\max }$ (neat) 3432 (br), $1770,1708,1398,1106,723 \mathrm{~cm}^{-1}$; ${ }^{1} \mathrm{H}-\mathrm{NMR}\left(\mathrm{CDCl}_{3}\right) \delta 1.80-1.90(\mathrm{~m}, 4 \mathrm{H}), 2.60-2.90(\mathrm{~m}, 12 \mathrm{H}), 3.51-3.64(\mathrm{~m}$, $16 \mathrm{H}), 3.68(\mathrm{t}, 4 \mathrm{H}, \mathrm{J}=7.1 \mathrm{~Hz}), 7.62-7.72(\mathrm{~m}, 4 \mathrm{H}), 7.78-7.85(\mathrm{~m}, 4 \mathrm{H}) ; \mathrm{MS}-\mathrm{EI} \mathrm{m} / 2636\left(\mathrm{M}^{+}\right)$, calcd. for $\mathrm{C}_{34} \mathrm{H}_{44} \mathrm{~N}_{4} \mathrm{O}_{8} \mathrm{~m} / 2636$.

4,13-Bis-(3-aminopropyl)-1,7,10,16-tetraoxa-4,13-diazacyclooctadecane (7). A solution of bisphthalimido derivative $6(2.0 \mathrm{~g}, 3.15 \mathrm{mmol})$ in $80 \mathrm{ml}$ of EtOH and hydrazine mono-hydrate $(3.05 \mathrm{ml}, 63$ $\mathrm{mmol}$ ) was heated to reflux with stirring for $5 \mathrm{~h}$, with formation of phthalidrazide as a heavy white precipitate. The reaction mixture was then allowed to cool to RT and filtered; the precipitate was carefully washed with 20 $\mathrm{ml}$ of cold EtOH. Evaporation of the combined filtrates under reduced pressure afforded $1.15 \mathrm{~g}(97 \%)$ of 7 as a light yellow oil: [Found: $\mathrm{C}, 57.25 ; \mathrm{H}, 10.59 ; \mathrm{N}, 14.72 . \mathrm{C}_{18} \mathrm{H}_{40} \mathrm{~N}_{4} \mathrm{O}_{4}$ requires $\mathrm{C}, 57.41 ; \mathrm{H}, 10.73 ; \mathrm{N}, 14.87$ ]; $\mathrm{V}_{\max }$ (neat) $3420(\mathrm{br}), 2906,1398,1110 \mathrm{~cm}^{-1}$; ${ }^{1} \mathrm{H}-\mathrm{NMR}\left(\mathrm{CDCl}_{3}\right) \delta 1.68-1.77(\mathrm{~m}, 4 \mathrm{H}), 2.57(\mathrm{t}, 8 \mathrm{H}, \mathrm{J}=4.8 \mathrm{~Hz}$ ), $2.68(\mathrm{t}, 4 \mathrm{H}, \mathrm{J}=6.8 \mathrm{~Hz}), 2.90(\mathrm{t}, 4 \mathrm{H}, \mathrm{J}=6.0 \mathrm{~Hz}), 3.49(\mathrm{t}, 8 \mathrm{H}, \mathrm{J}=4.8 \mathrm{~Hz}), 3.57(\mathrm{~s}, 8 \mathrm{H}), 5.38\left(\mathrm{br} . \mathrm{s}, 4 \mathrm{H}, \mathrm{D}_{2} \mathrm{O}\right.$ exchange); MS-EI m/z $376\left(\mathrm{M}^{+}\right)$, calcd. for $\mathrm{C}_{18} \mathrm{H}_{40} \mathrm{~N}_{4} \mathrm{O}_{4} \mathrm{~m} / \mathrm{z} 376$.

4,13-Bis-(6-[2,4-bis-(n-butylamino)-1,3,5-triazin-6-yl]-n-propylamino)-1,7,10,16-tetraoxa-4,13diazacyclooctadecane (2). Solid $\mathrm{K}_{2} \mathrm{CO}_{3}(6.8 \mathrm{~g}, 49.3 \mathrm{mmol})$ was added to a solution of the bis-n-butylamino derivative $4(1.37 \mathrm{~g}, 5.32 \mathrm{mmol})$ and $7(1.0 \mathrm{~g}, 2.66 \mathrm{mmol})$ in $100 \mathrm{ml}$ of $\mathrm{CH}_{3} \mathrm{CN}$. The resulting suspension was stirred at reflux for $22 \mathrm{~h}$. The reaction mixture was allowed to cool to RT and filtered through Celite; the precipitate was carefully washed with $20 \mathrm{ml}$ of $\mathrm{CH}_{3} \mathrm{CN}$ and the filtrates were evaporated to dryness under reduced pressure to afford $1.0 \mathrm{~g}(46 \%)$ of 2 as a pale yellow viscous oil; [Found: $\mathrm{C}, 58.51 ; \mathrm{H}, 9.71 ; \mathrm{N}, 23.82$. $\mathrm{C}_{40} \mathrm{H}_{78} \mathrm{~N}_{14} \mathrm{O}_{4}$ requires $\left.\mathrm{C}, 58.65 ; \mathrm{H}, 9.60 ; \mathrm{N}, 23.94\right] ; v_{\max }(\mathrm{KBr}) 3396(\mathrm{br}), 2957,2872,1666,1563,1527,1354$, 
$1104 \mathrm{~cm}^{-1} ;{ }^{1} \mathrm{H}-\mathrm{NMR}\left(\mathrm{CDCl}_{3}\right) \delta 0.90(\mathrm{t}, 12 \mathrm{H}, \mathrm{J}=7.2 \mathrm{~Hz}), 1.29-1.44(\mathrm{~m}, 8 \mathrm{H}), 1.45-1.58(\mathrm{~m}, 8 \mathrm{H}), 1.60-1.75(\mathrm{~m}$, 4H), 1.84-1.96 (m, 6H), 2.48-2.80 (br. m, 16H), 3.22-3.40 (m, 8H), 3.45-3.68 (m, 16H); MS-FAB( $\left.{ }^{+}\right)$, m/z 857 $\left(\mathrm{M}^{+}, \mathrm{K}^{+}\right)$, calcd. for $\mathrm{C}_{40} \mathrm{H}_{78} \mathrm{~N}_{14} \mathrm{O}_{4} \mathrm{~K} \mathrm{~m} / \mathbf{2} 857$.

9-[(4-Methylphenyl)-sulfonyl]-3,6,12,15-tetraoxa-9-aza-1,17-heptanediol (9). A mixture of ptoluensulfonamide $(17.12 \mathrm{~g}, 0.1 \mathrm{~mol})$, triethyleneglycol chlorohydrin $(43.84 \mathrm{~g}, 0.26 \mathrm{~mol})$ and $\mathrm{K}_{2} \mathrm{CO}_{3}(69.2 \mathrm{~g}$, $0.5 \mathrm{~mol}$ ) in $200 \mathrm{ml}$ of DMF was heated at $100^{\circ} \mathrm{C}$ and stirred for 4 days. After cooling at RT the reaction mixture was filtered over Celite and the precipitate carefully washed with $70 \mathrm{ml}$ of cold DMF. The filtrates were evaporated under reduced pressure and the residue $(51.27 \mathrm{~g})$ was purified by column cromatography $\left(\mathrm{SiO}_{2}\right.$, EtOAc) to afford $38.08 \mathrm{~g}(87.5 \%)$ of 9 as a colourless thick oil; [Found: C, 52.17; H, 7.58; N, 3.15. $\mathrm{C}_{19} \mathrm{H}_{33} \mathrm{NO}_{8} \mathrm{~S}$ requires $\mathrm{C}, 52.39 ; \mathrm{H}, 7.65 ; \mathrm{N}, 3.21$ ]; $v_{\max }$ (neat) 3400 (br), 2873, 1666, 1337, 1158, $1125 \mathrm{~cm}^{-1}$; ${ }^{1} \mathrm{H}-\mathrm{NMR}\left(\mathrm{CDCl}_{3}\right) \delta 2.35(\mathrm{~s}, 3 \mathrm{H}), 3.31(\mathrm{t}, 4 \mathrm{H}, \mathrm{J}=6.0 \mathrm{~Hz}), 3.36$ (br. s, $2 \mathrm{H}, \mathrm{D}_{2} \mathrm{O}$ exchange), 3.47-3.55 (m, 12H), 3.58-3.66 (m, 8H), $7.20(\mathrm{~d}, 2 \mathrm{H}, \mathrm{J}=8.2 \mathrm{~Hz}), 7.60(\mathrm{~d}, 2 \mathrm{H}, \mathrm{J}=8.2 \mathrm{~Hz})$.

9-[-[(4-Methylphenyl)-sulfonyl]-3,6,12,15-tetraoxa-9-aza-1,17-heptanediol-bis-(methanesulfonate) (10). Methanesulfonyl chloride $(21.47 \mathrm{~g}, 188 \mathrm{mmol})$ was added in $1 \mathrm{~h}$ to a solution of $9(39.08 \mathrm{~g}, 89.5 \mathrm{mmol})$ in $170 \mathrm{ml}$ of pyridine, the temperature being kept below $0^{\circ} \mathrm{C}$. The reaction mixture was maintained at $0^{\circ} \mathrm{C}$ for further $2 \mathrm{~h}$ and then left overnight in the refrigerator. After this time, the mixture was poured into crushed ice, acidified with 37\% aqueous $\mathrm{HCl}$ and extracted with $\mathrm{CH}_{2} \mathrm{Cl}_{2}(2 \times 100 \mathrm{ml})$. The organic phase was washed with brine ( $2 \times 60 \mathrm{ml}$ ), dried over $\mathrm{MgSO}_{4}$ and evaporated to dryness to afford $52.18 \mathrm{~g}(98.4 \%)$ of 10 as a red thick oil; [Found: $\mathrm{C}, 42.75 ; \mathrm{H}, 6.40 ; \mathrm{N}, 2.30 . \mathrm{C}_{21} \mathrm{H}_{37} \mathrm{NO}_{12} \mathrm{~S}_{3}$ requires $\mathrm{C}, 42.63 ; \mathrm{H}, 6.32 ; \mathrm{N}, 2.37$ ]; $\mathrm{v}_{\max }$ (neat) 3029, $2940,1455,1353,1175,1018,975,924,815 \mathrm{~cm}^{-1}$; ${ }^{1} \mathrm{H}-\mathrm{NMR}\left(\mathrm{CDCl}_{3}\right) \delta 2.35(\mathrm{~s}, 3 \mathrm{H}), 3.00(\mathrm{~s}, 6 \mathrm{H}), 3.20-3.70$ $(\mathrm{m}, 20 \mathrm{H}), 4.20-4.40(\mathrm{~m}, 4 \mathrm{H}), 7.20(\mathrm{~d}, 2 \mathrm{H}, \mathrm{J}=8.2 \mathrm{~Hz}), 7.60(\mathrm{~d}, 2 \mathrm{H}, \mathrm{J}=8.2 \mathrm{~Hz})$.

4-Benzyl-13-[(4-methylphenyl)-sulfonyl]-1,7,10,16-tetraoxa-4,13-diazacyclooctadecane (11). A mixture of the bis methanesulfonate derivative $10(52.18 \mathrm{~g}, 88.2 \mathrm{mmol})$, benzylamine $(9.45 \mathrm{~g}, 88.2 \mathrm{mmol})$ and anhydrous $\mathrm{Na}_{2} \mathrm{CO}_{3}(28.1 \mathrm{~g}, 265 \mathrm{mmol})$ in $500 \mathrm{ml}$ of $\mathrm{CH}_{3} \mathrm{CN}$ was refluxed for $72 \mathrm{~h}$ with vigorous stirring. The reaction mixture, cooled at RT, was filtered over Celite; the precipitate was washed with $150 \mathrm{ml}$ of $\mathrm{CH}_{3} \mathrm{CN}$ and the filtrate was evaporated to dryness. The residue $(50 \mathrm{~g}$ of thick oil) was purified by column cromatography $\left(\mathrm{SiO}_{2}\right.$, EtOAc) to afford $20.11 \mathrm{~g} \mathrm{(45 \% )}$ of 7 as very thick yellow oil; [Found: $\mathrm{C}, 61.57 ; \mathrm{H}, 7.45$; $\mathrm{N}, 5.48$. $\mathrm{C}_{26} \mathrm{H}_{38} \mathrm{~N}_{2} \mathrm{O}_{6} \mathrm{~S}$ requires $\mathrm{C}, 61.63 ; \mathrm{H}, 7.57 ; \mathrm{N}, 5.53$ ]; $\mathrm{v}_{\max }$ (neat) 2868; 1599, 1494, 1453, 1342, 1154, $1120 \mathrm{~cm}^{-1}$; ${ }^{\mathrm{H}} \mathrm{H}-\mathrm{NMR}\left(\mathrm{CDCl}_{3}\right)$ d $2.40(\mathrm{~s}, 3 \mathrm{H}), 2.60-3.10(\mathrm{~m}, 4 \mathrm{H}), 3.20-3.80(\mathrm{~m}, 22 \mathrm{H}), 7.10-7.40(\mathrm{~m}, 7 \mathrm{H}), 7.70$ $(d, 2 \mathrm{H}, \mathrm{J}=8.2 \mathrm{~Hz})$; $\mathrm{MS}-\mathrm{FAB}\left({ }^{+}\right) \mathrm{m} / \mathrm{z} 529\left(\mathrm{M}^{+}, \mathrm{Na}^{+}\right), 506\left(\mathrm{M}^{+}\right)$; calcd. for $\mathrm{C}_{26} \mathrm{H}_{38} \mathrm{~N}_{2} \mathrm{O}_{6} \mathrm{SNa}, \mathrm{m} / \mathrm{z} 529\left(\mathrm{M}^{+}, \mathrm{Na}^{+}\right)$, $506\left(M^{+}\right)$.

4-Benzyl-1,7,10,16-tetraoxa-4,13-diazacyclooctadecane (8). A solution of $11(3.0 \mathrm{~g}, 5.9 \mathrm{mmol})$ in 40 ml of dry THF was slowly added to a magnetically stirred suspension of $\mathrm{LiAlH}_{4}(1.13 \mathrm{~g}, 29.6 \mathrm{mmol})$ in $20 \mathrm{ml}$ of dry THF in an inert atmosphere. After the addition was completed, the reaction mixture was refluxed and stirred for 4 days, then allowed to cool at RT and the excess of $\mathrm{LiAlH}_{4}$ was decomposed with the stoichiometric amount of $\mathrm{H}_{2} \mathrm{O}$. The aluminium oxide was filtered off and carefully washed with $50 \mathrm{ml}$ of THF; the filtrates, evaporated under reduced pressure, gave $1.8 \mathrm{~g}(86.2 \%)$ of 8 as light yellow oil; [Found: C, 64.82; $\mathrm{H}, 9.23 ; \mathrm{N}, 8.02$. $\mathrm{C}_{19} \mathrm{H}_{32} \mathrm{~N}_{2} \mathrm{O}_{4}$ requires $\left.\mathrm{C}, 64.73 ; \mathrm{H}, 9.17 ; \mathrm{N}, 7.94\right] ; v_{\max }$ (neat) $3480,2873,1624,1455,1352$, $1117 \mathrm{~cm}^{-1}$; ${ }^{1} \mathrm{H}-\mathrm{NMR}\left(\mathrm{CDCl}_{3}\right) 82.70-2.90$ (m, 8H), 3.10 (br. s, $1 \mathrm{H}, \mathrm{D}_{2} \mathrm{O}$ exchange), 3.40-3.70 (m, 18H), 7.20$7.40(\mathrm{~m}, 5 \mathrm{H})$; MS-FAB( $\left.{ }^{+}\right) \mathrm{m} / \mathrm{z} 375\left(\mathrm{M}^{+}, \mathrm{Na}^{+}\right), 352\left(\mathrm{M}^{+}\right)$; calcd. for $\mathrm{C}_{19} \mathrm{H}_{32} \mathrm{~N}_{2} \mathrm{O}_{4} \mathrm{Na}, \mathrm{m} / \mathrm{z} 375\left(\mathrm{M}^{+}, \mathrm{Na}^{+}\right), 352$ $\left(\mathbf{M}^{+}\right)$.

4-Benzyl-13-[2,4-bis-(n-butylamino)-1,3,5-triazin-6-yl]-1,7,10,16-tetraoxa-4,13-diazacyclooctadecane (3). Solid $\mathrm{K}_{2} \mathrm{CO}_{3}(1.38 \mathrm{~g}, 10 \mathrm{mmol})$ was added to a solution of $8(0.90 \mathrm{~g}, 2.55 \mathrm{mmol})$ and the bis- $n$-butylamino derivative $4(0.95 \mathrm{~g}, 3 \mathrm{mmol})$ in $20 \mathrm{ml}$ of DMF; the resulting suspension was stirred at $130{ }^{\circ} \mathrm{C}$ for $24 \mathrm{~h}$. The reaction mixture was evaporated to dryness, taken up in $\mathrm{CH}_{2} \mathrm{Cl}_{2}$ and filtered through Celite; the precipitate was carefully washed with $30 \mathrm{ml}$ of $\mathrm{CH}_{2} \mathrm{Cl}_{2}$ and the filtrates were evaporated to dryness under reduced pressure. The residue was purified by column cromatography $\left(\mathrm{SiO}_{2}, \mathrm{CH}_{2} \mathrm{Cl}_{2} / \mathrm{MeOH} 9 / 1\right)$ to give $0.81 \mathrm{~g} \mathrm{(55 \% )}$ of 3 as thick oil; [Found: $\mathrm{C}, 62.93 ; \mathrm{H}, 8.87 ; \mathrm{N}, 17.31 . \mathrm{C}_{30} \mathrm{H}_{51} \mathrm{~N}_{7} \mathrm{O}_{4}$ requires $\mathrm{C}, 62.80 ; \mathrm{H}, 8.96 ; \mathrm{N}, 17.09$ ]; $\mathrm{v}_{\max }$ (neat) 
2956, 2930, 2870, 1553, 1509, $1118 \mathrm{~cm}^{-1} ;{ }^{1} \mathrm{H}-\mathrm{NMR}\left(\mathrm{CDCl}_{3}\right) \delta 0.90(\mathrm{t}, 6 \mathrm{H}, \mathrm{J}=7.2 \mathrm{~Hz}), 1.29-1.41(\mathrm{~m}, 4 \mathrm{H})$, $1.46-1.52(\mathrm{~m}, 4 \mathrm{H}), 2.81(\mathrm{t}, 4 \mathrm{H}, \mathrm{J}=5.9 \mathrm{~Hz}), 3.30(\mathrm{q}, 4 \mathrm{H}, \mathrm{J}=6.3 \mathrm{~Hz}), 3.59-3.72(\mathrm{~m}, 18 \mathrm{H}), 3.75-3.86(\mathrm{~m}, 4 \mathrm{H})$, 4.75 (br. s, 4H, $\mathrm{D}_{2} \mathrm{O}$ exchange), 7.20-7.40 (m, SH); MS-FAB( $\left.{ }^{+}\right) \mathrm{m} / \mathrm{z} 574\left(\mathrm{M}^{+}, \mathrm{H}^{+}\right)$; calcd. for $\mathrm{C}_{30} \mathrm{H}_{51} \mathrm{~N}_{7} \mathrm{O}_{4}, \mathrm{~m} / 2$ $573\left(M^{+}\right)$.

UV-Vis titrations. A quartz optical cell of $1 \mathrm{~cm}$ pathlength was charged with $3.0 \mathrm{ml}$ of solution of the receptor $\left(4.0-7.0 \times 10^{-5} \mathrm{M}\right.$ for 1 and $1.8-3.0 \times 10^{-5} \mathrm{M}$ for 2$)$ in $\mathrm{CH}_{3} \mathrm{CN}$. The solution was titrated by adding 5$10 \mu$ aliquots of $\mathrm{M}\left(\mathrm{ClO}_{4}\right)_{2}$ solution $\left(2.0-9.5 \times 10^{-3} \mathrm{M}\right.$ in $\left.\mathrm{CH}_{3} \mathrm{CN}\right)$ until the excess of metal cation with respect to the receptor was 2-3 times. The UV-Vis spectra of the starting solution and of those after each addition were recorded in the 350-190 nm region. The progress of the absorbance value at $250 \mathrm{~nm}$ was used for the evaluation of complex $[\mathrm{M} \subset \mathrm{L}]^{2+}$ stoichiometry and for the calculation of the stability constant $\mathrm{K}_{\mathrm{S}}$ according to Eqn. 1 (see above). The volume change due to the addition of the $\mathrm{M}\left(\mathrm{ClO}_{4}\right)_{2}$ solution was negligible and the initial concentration of the receptor $\mathrm{C}_{0}$ could be considered constant in the iterative nonlinear calculation of KS.

Solid/iquid complexation experiments. Into a $20 \mathrm{ml}$ centrifuge test tube were introduced $5 \mathrm{ml}$ of a $2 \times$ $10^{-2} \mathrm{M}$ solution of the receptor in $\mathrm{CHCl}_{3}, 1 \mathrm{mmol}$ of solid salt and a small stirring bar. The tube was stoppered to prevent evaporation, magnetically stirred for $2 \mathrm{~h}$ at $20^{\circ} \mathrm{C}$ and then centrifuged at $3000 \mathrm{rpm}$ for $10 \mathrm{~min}$. A 2 $\mathrm{ml}$ aliquot of the clear organic solution was diluted with $50 \mathrm{ml}$ of $\mathrm{MeOH}$, acidified with $\mathrm{HNO}_{3}$ and finally potentiometrically titrated with aqueous $1 \times 10^{-2} \mathrm{M} \mathrm{AgNO}_{3}$. The amount of halide determined in this way corresponds to $\left[(M \subset L)^{+} X^{-}\right]$(Eqn. 2).

\section{REFERENCES}

1. a) Lehn, J.-M. Supramolecular Chemistry, VCH: Weinheim, 1995; pp. 37-53; b) Lawrence, D. S.; Jang, T.; Levett, M. Chem. Rev. 1995, 95, 2229-2260.

2. a) Kim, M.S.; Gokel, G. W. J. Chem. Soc., Chem. Commun. 1987, 1686-1687; b) Schall, O. F.; Gokel, G. W. J. Am. Chem. Soc. 1994, 116, 6089-6100.

3. a) Quici,S.; Manfredi, A.; Buttafava, M. J. Org. Chem. 1996, 61, 3870-3873; b) Quici,S.; Manfredi, A.; Rossi, R.; Campagna, S.; Calogero, G.; Balzani, V. Gazz. Chim. It. 1997, 127, 107-109 c) Di Pietro, C.; Guglielmo, G.; Campagna, S.; Diotti, M.; Manfredi, A.; Quici, S. New J. Chem. 1998, 22, 1037-1039.

4. a) Lindsey, J. S. New J. Chem. 1991, 15, 153-180; b) Tjivikna, T.; Ballester, P.; Rebek Jr, J. J. Am. Chem. Soc. 1990, 112, 1249-1250.

5. a) Izatt, R. M.; Pawlak, K.; Bradshaw, J. S.; Bruening, R. L. Chem. Rev. 1995, 95, 2529-2586; b) Mitewa, M.; Bontchev, P. R. Coord. Chem. Rev. 1994, 135/136, 129-163.

6. Lehn, J.-M.; Mascal, M.; Deciau, A.; Fisher, J. J. Chem. Soc., Chem. Commun. 1990, 479-481.

7. Whitesides, G. M.; Simanek, E. E.; Mathias, J. P.; Seto, C. T.; Chin, D. N.; Mammen, M.; Gordon, D. M. Acc. Chem. Res. 1995 28, 37-44 and references cited therein.

8. Schall, O. F.; Gokel, G. W. J. Org. Chem. 1996, 61, 1449-1458.

9. Anelli, P. L.; Montanari, F.; Quici, S. J. Org. Chem. 1988, 53, 5292-5298.

10. Connors, K. A. Binding Constants - The Measurement of Molecular Complex Stability; John Wiley and Sons: New York, 1987; pp. 141-147.

11. Bourson, J.; Pouget, J.; Valeur, B. J. Phys. Chem. 1993, 97, 4552-4557.

12. Chriswell, C. D.; Schilt, A. A. Anal. Chem. 1975, 47, 1623-1629.

13. Izatt, R. M.; Bradshaw, J. S.; Nielsen, S. A.; Lamb, J. D. Chem. Rev. 1985, 85, 271-339.

14. Lehn, J.-M.; Vierling, P. Tetrahedron Lett. 1980, 21, 1323-1326.

15. Quici, S.; Manfredi, A.; Pozzi, G.; Campagna, S.; Serroni, S.; Balzani, V. unpublished results. 